\title{
Cassava (manihot esculenta cranz) foliage replacing brewer's grains as protein supplement for yellow cattle fed a basal diet of cassava pulp-urea and rice
}

\section{straw}

\begin{abstract}
Twelve local "Yellow" cattle with initial weight from 114 to $117 \mathrm{~kg}$ and 1.8 to 2 years of age were allocated in a completely randomized block design to 4 treatments and 3 replicates. The treatments (as supplements to ad libitum cassava pulp plus $3 \%$ urea on DM basis and rice straw $1 \%$ of LW) were: cassava foliage and brewers' grains in the ratio 4:0, 3:1, 2:2 and 0:4 as \% of live weight, fresh basis. The experiment was carried out for 120 days from February to July 2016. At the end of the trial, concentrations of methane and carbon dioxide were determined in eructed gas mixed with air in a closed chamber in which the animals were kept for 20 minutes prior to measurement of the gases. There was a quadratic relationship between the rate of live weight and the proportion of brewers' grains in the diet DM, with the maximum growth rate being recorded when the brewers' grains provided $15 \%$ of the diet DM. There was a similar relationship between level of brewers' grains and DM feed conversion with the optimum value at about $17 \%$ of brewers' grains in the diet DM. The ratio of methane to carbon dioxide in mixed eructed gas and air declined with a curvilinear trend as the fresh cassava foliage replaced brewers' grains in the diet.
\end{abstract}

Keywords: cassava foliage, brewers grains, urea, rice straw, cassava pulp, yellow cattle
Volume 2 Issue 3 - 2017

\section{Toum Keopaseuth, Preston TR \\ Livestock Research Center, National agriculture and forestry research institute, Colombia}

Correspondence: Toum Keopaseuth, Livestock Research Center, National agriculture and forestry research institute, Ministry of Agriculture and Forestry, PO Box 6644Vientiane, Lao PDR, Colombia, Email Toum_I@yahoo.com

Received: May 16, 2017| Published: July 21, 2017

\section{Introduction}

A recent development in Lao PDR is the industrial production of starch for export using cassava roots as the feedstock. There are presently 5 factories in operation with a yearly demand of 200,000 tones of cassava roots. The extracted starch accounts for some $60 \%$ of the root DM, the remainder being a byproduct known as cassava pulp. Recent research has demonstrated that the pulp has nutritive values only slightly less than that of the original cassava $\operatorname{root}^{1}$ and can be used as the basis of an intensive system of cattle fattening. The first demonstration of this system ${ }^{2}$ was based on the use of urea, brewers' grains and rice straw as sources of the fermentable nitrogen, bypass protein and fiber needed to complement the cassava pulp which contains negligible quantities of protein $(<3 \%$ in DM) and crude fiber $(<10 \%$ in DM). However, farmer access to brewers grains is limited to the immediate area in which beer factories are found. Cassava production is rich in three part of Lao PDR, it can make many kind of foods for people and animal in fresh and dry, the cassava leaves is source of protein content according to many reports Cassava contains high protein (20-27\% crude protein), 25\% DM depend on age, residue of cassava factory we call cassava pulp were abandon cause pollution. Cassava pulp is source of carbohydrate feed of animals. Another source of bypass protein is cassava foliage. ${ }^{3-6}$ Cassava foliage is available as a byproduct of root production or can be grown as a semi-perennial forage (Preston 2005). It has been fed successfully to improve performance of sheep, ${ }^{7}$ goats (Ho Quang Do et al $2001^{8}$ and cattle 5,9 in fresh, wilted or dried form. Cassava leaves are known to contain variable levels of condensed tannins; about $3 \%$ in DM according to ${ }^{10}$ and Bui Phan Thu Hang and Ledin (2005). Cassava also contains cyanogenic glucosides, mainly linamarin, which release hydrogen cyanide after hydrolysis in the rumen by an endogenous linamarase (Butler et al 1965). Methane production was inhibited in anaerobic biodigesters charged with cassava root waste because of the high sensitivity of methanogenic bacteria to cyanide (Eikmanns and Thauer 1984. ${ }^{11,12}$ Reduced production of methane was observed when cassava foliage was the protein source in an in vitro rumen fermentation of molasses-urea. ${ }^{13}$ The purpose of the present study was to determine the effect of cassava foliage as protein source replacing brewers' grains in diets for growing cattle fed cassava pulpurea and rice straw as the basal diet.

\section{Materials and methods}

\section{Location and duration}

The experiment was conducted in the Livestock Research Center, $44 \mathrm{~km}$ from Vientiane city Lao PDR from December 2015 to May, 2016.

\section{Treatments and experimental design}

A completely randomized block design was used with 4 treatments and 3 replicates. The treatments as supplements to ad libitum cassava pulp (plus 3\% urea on DM basis), rice straw at $1 \%$ of LW (fresh basis) and minerals were:

a. BG4: Brewers' grains at $4 \%$ of LW (fresh basis)

b. BG2-CF2: Fresh cassava foliage $2 \%$ of LW+BG $2 \%$ LW (fresh basis)

c. BG1-CF3: Fresh cassava foliage 3\% LW+BG 1\% of LW (fresh basis) 


\section{d. BG0-CF4: Fresh cassava foliage at $4 \%$ of LW (fresh basis)}

\section{Animals and housing}

Twelve male "Yellow" cattle, average age 1.5 years and initial weight $114-117 \mathrm{~kg}$ were purchased from farmers and housed in individual pens (Photo 1). They were treated for internal and external parasites with Ivomex-F and vaccinated against Foot and Mouth Disease.

\section{Feeding management}

Cassava foliage (sweet variety) was planted on an area of $2000 \mathrm{~m}^{2}$ in the Livestock Research Center. The foliage (leaves, petioles and stems) were harvested at 55 day intervals. With an expected yield of $2 \mathrm{~kg}$ fresh foliage $/ \mathrm{m}^{2}$, an area of $15 \mathrm{~m}^{2}$ was harvested daily increasing to $30 \mathrm{~m}^{2} /$ day by the end of the experiment. Brewers' grains were purchased (about $3000 \mathrm{~kg}$ fresh basis) from the brewery and ensiled in polyethylene bags enclosed inside sacks of polypropylene (Photo 2). Cassava root pulp (about $5000 \mathrm{~kg}$ ) was collected from the Indochina Tapioca factory and ensiled in the same way as the brewers' grains. The cattle were adapted gradually to the experimental feeds beginning with ad libitum rice straw which was reduced gradually to $1 \mathrm{~kg} /$ head per day after 14 days with other components of the diet being increased gradually over the same period. A solution of urea (1 part urea; 3 parts water) was mixed with the cassava pulp at the rate of $6 \mathrm{~g}$ urea per $1 \mathrm{~kg}$ of ensiled pulp. The urea-supplemented pulp was fed ad libitum (expected intake was about $10 \mathrm{~kg}$ per $100 \mathrm{~kg} \mathrm{LW}$ ). The rice straw was given in two equal feeds (am and pm). Total requirements were $1500 \mathrm{~kg}$ which was procured at the beginning of the experiment.

\section{Data collection and measurements}

The cattle were weighed before feeding in the morning at the beginning of the experiment and at 14 day intervals. Feed offered and residues were recorded daily to determine feed intake. Chemical composition of feeds (DM, N, NDF, ash) was determined on representative samples of feed and feed refusals at 14 day intervals. The $\mathrm{pH}$ of the ensiled cassava pulp and ensiled brewers' grains was recorded at weekly intervals.

\section{Methane in eructed gases}

After 90 days the cattle were confined individually in a gas-proof chamber (a bamboo frame covered with polyethylene) for sampling of eructed gases and residual air in the chamber. Measurements of the concentrations of methane and carbon dioxide were taken continuously over a 10 minute period, using a Gasmet infra-red meter (GASMET 4030; Gasmet Technologies Oy, Pulttitie 8A, FI-00880 Helsinki, Finland), following the procedure outlined by. ${ }^{14}$

\section{Statistical analysis}

Mean values for effects of supplementation on weight gain, feed intake and feed conversion were compared using the general linear model (GLM) option of the analysis of variance software in Minitab (2016). Sources of variation in the model were: treatments, replicates and error. Quadratic equations were fitted to the data to demonstrate trends in responses (y) for live-weight gain and feed conversion against dietary levels of brewers' grains $(\mathrm{x})$ and between methane: carbon dioxide ratio (y) and percent cassava foliage in the diet (x).

\section{Results}

\section{Growth and feed conversion}

The $16.4 \%$ crude protein in the DM of the harvested cassava foliage (Table 1) was similar to the value of $17.3 \%$ reported by ${ }^{13}$ for cassava foliage fed to goats in Vietnam, and reflected the presence of petioles and young stems, along with the leaves, in the harvested foliage. Due to the lower content of crude protein in the cassava foliage ( $16.4 \%$ in DM) compared with the brewers' grains $(24.8 \%$ in $\mathrm{DM})$, the overall level of crude protein in the diet DM increased from 9.90 to $13.0 \%$ as the level of brewers' grains was increased (Table 2). However, despite these differences the overall DM intake was not affected by the changing ratio of cassava foliage to brewers' grains (Table 3) (Figure 1). There was a quadratic relationship between the rate of live weight and the proportion of brewers' grains in the diet $\mathrm{DM}$, with the maximum growth rate being recorded when the brewers' grains provided $15 \%$ of the diet DM, thereafter declining (Figure 2). There was a similar relationship between level of brewers' grains and DM feed conversion with the optimum value at about $17 \%$ of brewers' grains in the diet DM (Figure 3).

Table I Chemical composition of diet ingredients

\begin{tabular}{lllll}
\hline & $\begin{array}{l}\text { Cassava } \\
\text { pulp }\end{array}$ & $\begin{array}{l}\text { Brewers' } \\
\text { grains }\end{array}$ & $\begin{array}{l}\text { Cassava } \\
\text { foliage }\end{array}$ & $\begin{array}{l}\text { Rice } \\
\text { straw }\end{array}$ \\
\hline DM, \% & 23.6 & 24.3 & 26.6 & 90.1 \\
As \% in DM & - & - & - & - \\
Crude protein & 2.6 & 24.8 & 16.4 & 3.1 \\
NDF & 34.8 & 32.8 & 42.8 & 67.8 \\
ADF & 28.7 & 22.6 & 33.4 & 43.1 \\
Ash & 4.48 & 6.3 & 9.7 & 13.6 \\
\hline
\end{tabular}

Table 2 Mean values for feed intake, crude protein in the diet and relative proportions of brewers' grains (BG) and cassava foliage (CF) in the diet of "Yellow" cattle fed ad libitum ensiled cassava pulp-urea with cassava foliage replacing ensiled brewers' grains ( $\mathrm{kg} / \mathrm{d}$ of rice straw fed on all treatments)

\begin{tabular}{lllllll} 
& CF4 & BGI:CF3 & BG2:CF2 & BG4 & SEM & P \\
\hline DM intake, g/d & & & & & & \\
\hline Cassava pulp & 1399 & 1393 & 1323 & 1379 & 52 & 0.99 \\
Brewers' grains & 0 & 287 & 534 & 1140 & 76 & \\
Cassava foliage & 987 & 748 & 467 & 0 & 37 & \\
Rice straw & 889 & 889 & 889 & 889 & & \\
Total & 3275 & 3317 & 3213 & 3408 & 132 & 0.77 \\
\hline \% in diet DM & & & & & & \\
\hline Crude protein & 9.94 & 10.8 & 11.4 & 13 & & \\
Brewers' grains & 0 & 8.7 & 16.6 & 33.5 & & \\
\hline
\end{tabular}

Table 3 Mean values for feed intake, change in live weight and DM feed conversion for "Yellow" cattle fed ad libitum ensiled cassava pulp-urea with cassava foliage (CF) replacing ensiled brewers' grains (BG) $(\mathrm{I} \mathrm{kg} / \mathrm{d}$ of rice straw fed on all treatments)

\begin{tabular}{lllllll}
\hline & CF4 & BGI:CF3 & BG2:CF2 & BG4 & SEM & P \\
\hline DM intake, g/d & 3275 & 3317 & 3213 & 3408 & 132 & 0.77 \\
\hline \multicolumn{2}{l}{ Live weight, kg } & & & & & \\
\hline Initial & 115 & 116 & 114 & 117 & 10.9 & 0.99 \\
Final & 166 & 177 & 173 & 170 & 11.4 & 0.92 \\
ADG, g/d & 528 & 654 & 625 & 563 & 105 & 0.83 \\
$\begin{array}{l}\text { DM } \\
\text { conversion\# }\end{array}$ & 6.74 & 5.59 & 5.58 & 6.16 & 1.06 & 0.84 \\
\hline
\end{tabular}

\#kg feed DM/kg live weight gain. 


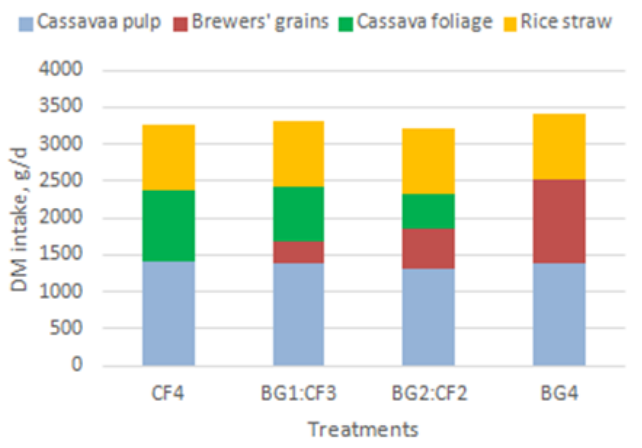

Figure I Effect of varying the offer levels of cassava foliage (CF) and brewers' grains $(B G)$ on the components of the diet DM consumed.

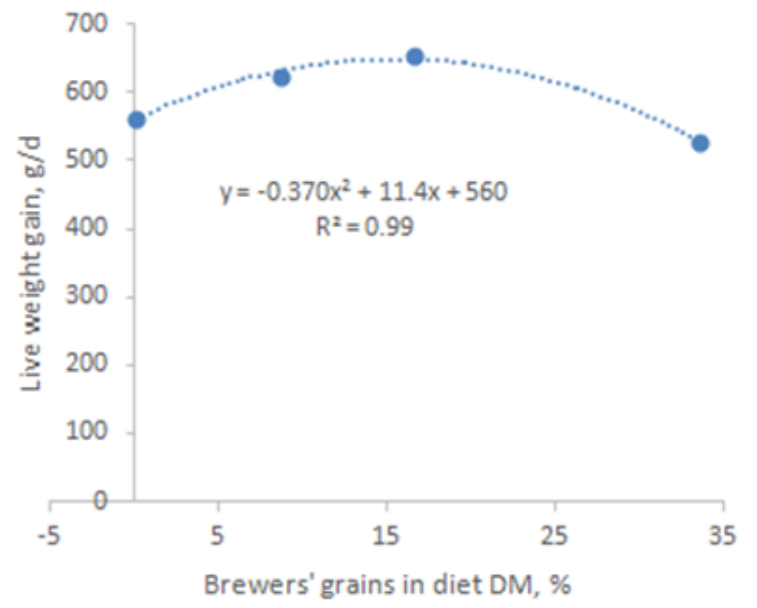

Figure 2 Growth rates of "Yellow" cattle fed cassava pulp/urea and increasing amounts of brewers' grains replacing fresh cassava foliage.

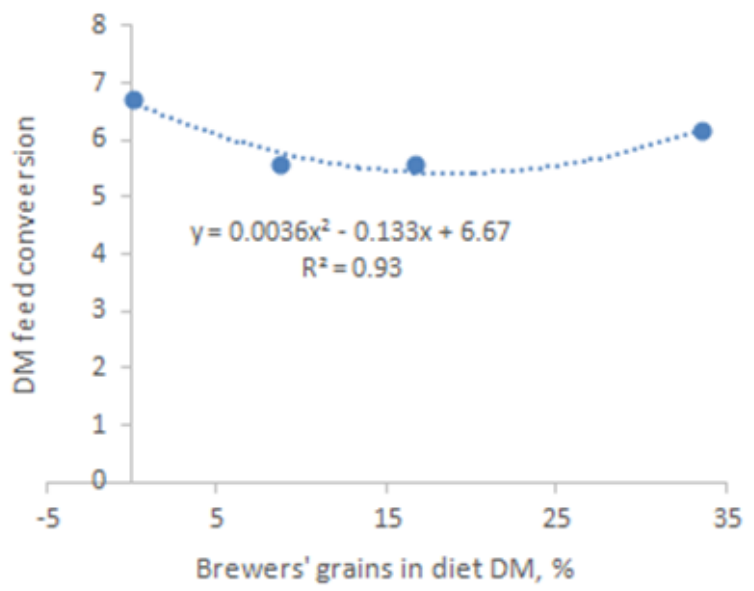

Figure 3 DM feed conversion of "Yellow" cattle fed cassava pulp/urea and increasing amounts of brewers' grains replacing fresh cassava foliage.

Methane: carbon dioxide ratio in eructed breath of the cattle

The ratio of methane to carbon dioxide (in the mixture of eructed gas and air in the plastic-enclosed chambers in which the cattle were confined individually over 10 minute periods) declined with a curvilinear trend as the fresh cassava foliage replaced brewers' grains in the diet (Table 4) (Figure 4).
Table 4 Mean values for the ratio methane: carbon dioxide in mixed eructed gases: air from "Yellow" cattle fed cassava pulp/urea and increasing amounts of fresh cassava foliage replacing brewers' grains

\begin{tabular}{|c|c|c|c|c|c|c|}
\hline \multicolumn{7}{|c|}{ Cassava foliage, \% in diet DM } \\
\hline & 0 & 15 & 23 & 30 & SEM & $P$ \\
\hline $\mathrm{CH}_{4}: \mathrm{CO}_{2}$ & $0.018^{a}$ & $0.0049^{b}$ & $0.003^{b}$ & $0.002^{\mathrm{b}}$ & 0.001 & $<0.001$ \\
\hline
\end{tabular}

ab: Means without common letter in the same row differ at $p<0.05$.

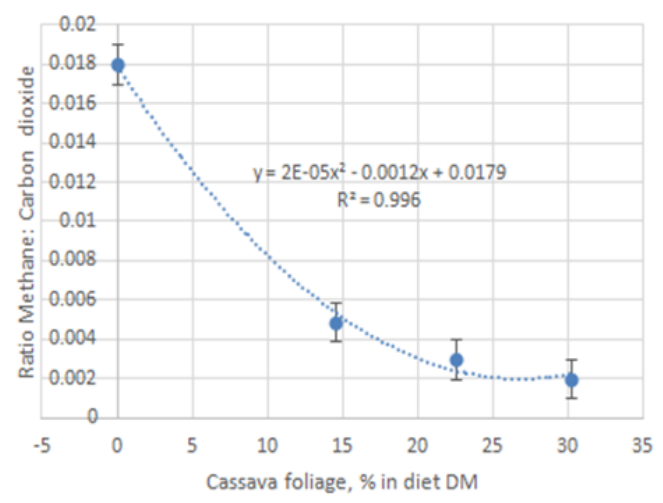

Figure 4 Increasing the proportions of fresh cassava foliage replacing brewers' grains reduced the methane: carbon dioxide ratio in mixed eructed gases: air from "Yellow" cattle fed cassava pulp/urea and rice straw.

\section{Discussion}

The benefits from brewers' grains, added to a cattle fattening diet based on cassava pulp-urea-cassava foliage, were first demonstrated by, ${ }^{16}$ when replacing $50 \%$ of the cassava foliage by brewers' grains (DM basis) led to almost doubling of the growth rate. In terms of diet composition this represented concentrations in the diet DM of brewers' grains of $20 \%$ and cassava foliage $20 \%$. In the present experiment the optimum combination appeared to be of the order of $9 \%$ brewers' grains and $23 \%$ of cassava foliage (in diet DM). The two experiments cannot be directly compared as in the research of ${ }^{17}$ the cassava was a "bitter" variety whereas in our study the cassava was a "sweet" variety. Phuong et al (2016, personal communication) reported major benefits in growth of cattle (from zero to $600 \mathrm{~g} /$ day) when brewers' grains (at only $4 \%$ of the diet DM) were added to a similar diet of cassava pulp-urea-cassava foliage. In this case the cassava was a bitter variety. It was also observed that urinary excretion of thiocyanate was substantially reduced by supplementation with the brewers' grains. These authors concluded that the benefits from the small amounts of brewers' grains ( $4 \%$ of diet DM) possibly were due to a "prebiotic" effect of this supplement in reducing the sub-clinical toxicity caused by the cyanogenic glucosides in the cassava foliage .

Discussion as to the nature of the chemical entities in brewers' grains that could be responsible for the apparent "prebiotic" action of this supplement is:

(i) Beyond the scope of this article; and

(ii) Requires more exhaustive research. Several in vitro studies have demonstrated that incorporation in the fermentation media of leaves from bitter, rather than sweet, cassava led to reduced production of methane ${ }^{18,19}$ The implication is that the generation of $\mathrm{HCN}$ in the in vitro or in vivo fermentation media, derived from the cyanogenic glucosides in the cassava leaves, is the 
direct cause of the toxicity to methane-producing organisms, as was demonstrated by ${ }^{20}$ in the anaerobic biodigestion of cassava root waste. Thus feeding bitter rather than sweet cassava foliage, and increasing the proportion of cassava foliage in the diet, will have the effect of increasing the potential for release of $\mathrm{HCN}$ in the fermentation medium, either in vitro or in vivo. The dramatic reduction in methane production observed in the present experiment as the proportion of cassava foliage in the diet was increased, corroborates this hypothesis. ${ }^{21-23}$

\section{Conclusion}

There was a quadratic relationship between the rate of live weight and the proportion of brewers' grains in the diet DM, with the maximum growth rate being recorded when the brewers' grains provided $15 \%$ of the diet DM, thereafter declining. There was a similar relationship between level of brewers' grains and DM feed conversion with the optimum value at about $17 \%$ of brewers' grains in the diet DM. The ratio of methane to carbon dioxide in mixed eructed gas and air declined with a curvilinear trend as the fresh cassava foliage replaced brewers' grains in the diet.

\section{Acknowledgements}

This research was done by the senior author as part of the requirements for the MSc degree in Animal sciences "Improving Livelihood and Food Security of the people in Lower Mekong Basin through Climate Change Mitigation" The authors are grateful to the MEKARN II project, financed by Sida, Sweden for the support for this research. Livestock Research Center (NAFRI) was acknowledged for provision of research facilities. . I am very grateful to my supervisor Assoc. Prof. Dr. Preston, for his endless assistance, discussing and providing comments and suggestions to accomplish this thesis.

\section{Conflict of interest}

The author declares no conflict of interest.

\section{References}

1. AOAC. Official methods of analysis. Association of official Analysis. 15 th ed. Washington, DC, USA; 1990.

2. Cuzin N, Labat M. Reduction of cyanide levels during anaerobic digestion of cassava. International Journal of Food Science. 1992;27:329-326.

3. Do HQ, Son VV, Thu Hang BP, et al. Effect of supplementation of ammoniated rice straw with cassava leaves or grass on intake, digestibility and $\mathrm{N}$ retention by goats. Livestock Research for Rural Development. 2002:14(3).

4. Ffoulkes D, Preston TR. Cassava or sweet potato forage as combined sources of protein and roughage in molasses based diets: effect of supplementation with soybean meal. 1978.

5. Hue KT, Van DTT, Ledin I, et al. Effect of feeding fresh, wilted and sun-dried foliage from cassava (Manihot esculenta Crantz) on the performance of lambs and their intake of hydrogen cyanide. Livestock Science. 2010;131:155-161.

6. Madsen J, Bjerg BS, Hvelplund TM, et al. Methane and carbon dioxide ratio in excreted air for quantification of the methane production from ruminants. Livestock Science. 2010;129:223-227.

7. Miller JM, Conn EE. Metabolism of hydrogen cyanide by higher plants. Plant Physiology. 1980;65:1199-1202.
8. Minitab. Minitab Release 13.31 for windows. USA: Minitab Inc., State College Pennsylvania; 2000.

9. Netpana N, Wanapat M, Poungchompu O, et al. Effect of condensed tannins in cassava hay on fecal parasitic egg counts in swamp buffaloes and cattle. In: Preston TR, Ogle B, Wanapat M, editors. Proceedings International Workshop on Current Research and Development on Use of Cassava as Animal Feed; 2001.

10. Phuong LTB, Preston TR, Leng RA. Effect of foliage from "sweet" and "bitter" cassava varieties on methane production in in vitro incubation with molasses supplemented with potassium nitrate or urea. Livestock Research for Rural Development. 2012:24(10).

11. Phengvichith V, Ledin I. Effects of supplementing gamba grass (Andropogon gayanus) with cassava (Manihot esculenta Crantz) hay and cassava root chips on feed intake, digestibility and growth in goats. Asian-Australasian Journal of Animal Sciences. 2007;20(5):725-732.

12. Phanthavong V, Viengsakoun N, Sangkhom I, et al. Cassava pulp as livestock feed; effects of storage in an open pit. Livestock Research for Rural Development. 2014;26(9):169.

13. Phanthavong V, Viengsakoun N, Sangkhom I, et al. Effect of biochar and leaves from sweet or bitter cassava on gas and methane production in an in vitro rumen incubation using cassava root pulp as source of energy. Livestock Research for Rural Development. 2015;27(4):72.

14. Phanthavong V, Khamla S, Preston TR. Fattening cattle in Lao PDR with cassava pulp. Livestock Research for Rural Development. 2016;28(1):10.

15. Phanthavong V, Preston TR, Viengsakoun N, et al. Brewers' grain and cassava foliage (Manihot esculenta Cranz) as protein sources for local "Yellow" cattle fed cassava pulp-urea as basal diet. Livestock Research for Rural Development. 2016;28(11):196.

16. Phuong LTB, Preston TR, Leng RA. Effect of foliage from "sweet" and "bitter" cassava varieties on methane production in in vitro incubation with molasses supplemented with potassium nitrate or urea. Livestock Research for Rural Development. 2012;24(10):189.

17. Promkot $\mathrm{C}$, Wanapat $\mathrm{M}$. Ruminal degradation and intestinal digestion of crude protein of tropical protein resources using nylon bag technique and three-step in vitro procedure in dairy cattle. Livestock Research for Rural Development. 2003;15(11):81.

18. Sath K, Borin K, Preston TR. Effect of levels of sun-dried cassava foliage on growth performance of cattle fed rice straw. Livestock Research for Rural Development. 2008:20.

19. Sengsouly P, Preston TR. Effect of rice-wine distillers' byproduct and biochar on growth performance and methane emissions in local "Yellow" cattle fed ensiled cassava root, urea, cassava foliage and rice straw. Livestock Research for Rural Development. 2016;28(10):178.

20. Smith MR, Lequerica JL, Hart MR. Inhibition of methanogenesis and carbon metabolism in Methanosarcina sp. by cyanide. J Bacteriol. 1985;162(1):67-71.

21. Thang CM, Ledin I, Bertilsson J. Effect of feeding cassava and/or Stylosanthes foliage on the performance of crossbred growing cattle. Trop Anim Health Prod. 2010;42(1):1-11.

22. Thanh TX, Hue KT, Anh NN, et al. Comparison of different forages as supplements to a basal diet of chopped cassava stems for growing goats. Livestock Research for Rural Development. 2013;25(1):7.

23. Wanapat M, Pimpa O, Petlum A, et al. Cassava hay: A new strategic feed for ruminants during the dry season. Livestock Research for Rural Development. 1997;9:18. 